NASZA DERMATOLOGIA Onlin OUR DERMATOLOGY Online

Source of Support:

Nil

Competing Interests:

None

\section{EPONYMS IN DERMATOLOGY LITERATURE LINKED TO GENITAL SKIN DISORDERS}

\author{
Khalid Al Aboud ${ }^{1}$, Ahmad Al Aboud ${ }^{2}$ \\ ${ }^{1}$ Department of Public Health, King Faisal Hospital, Makkah, Saudi Arabia \\ ${ }^{2}$ Dermatology Department, King Abdullah Medical City, Makkah, Saudi Arabia
}

Corresponding author: Dr. Khalid Al Aboud

amoa65@hotmail.com
There are numerous eponymous systemic diseases which may affect genital skin or sexual organs in both genders. For example Behçet disease which is characterized by relapsing oral aphthae, genital ulcers and iritis.

This disease is named after Hulusi Behçet [1] (1889-1948), (Fig. 1), the Turkish dermatologist and scientist who first recognized the syndrome. This disease also called „Adamantiades” syndrome” or „Adamandiades-Behçet syndrome", for the work done by Benediktos Adamantiades. Benediktos Adamantiades (1875-1962), (Fig. 2) was a Greek ophthalmologist [2].

Another example of systemic disease with genital involvement is Reiter syndrome which is recently called reactive arthritis. This syndrome is characterized by arthritis, urethritis, and conjunctivitis.

It is named after German physician Hans Reiter [3] (18811969), (Fig. 3). However, the name „Reiter's syndrome”, has become unpopular in the past decade as Reiter's history of Nazi party membership, forced human experimentation in the Buchenwald concentration camp, and subsequent prosecution in Nuremberg as a war criminal, have come to light.

One more example is syphilis. In 1530, the name „syphilis” was first used by the Italian physician and poet Girolamo Fracastoro [4] (1478-1553), as the title of his Latin poem in dactylic hexameter describing the ravages of the disease in Italy. In his well-known poem „Syphilidis sive de morbo gallico libri tres" (Three books on syphilis or the French disease), he coined the name by which we now know the disease from the legend of a shepherd called Syphilus who had purportedly gotten the illness as a punishment for defying the gods.

In Table I [5-20], however, we highlighted in particular to eponymous conditions which are primarily a disorders of genital area.

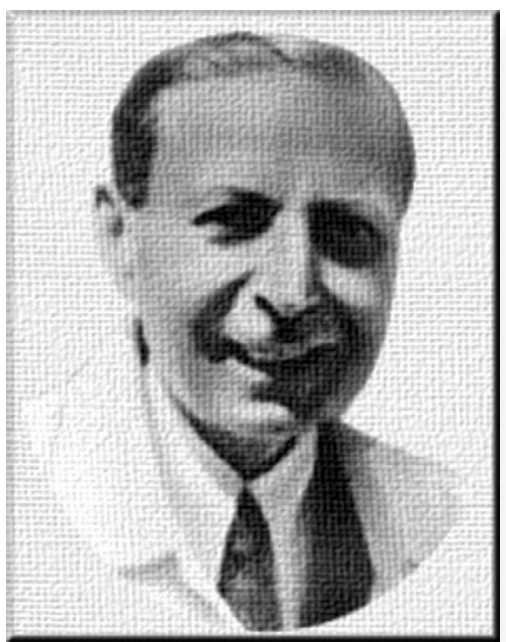

Figure 1. Hulusi Behçet (1889-1948)

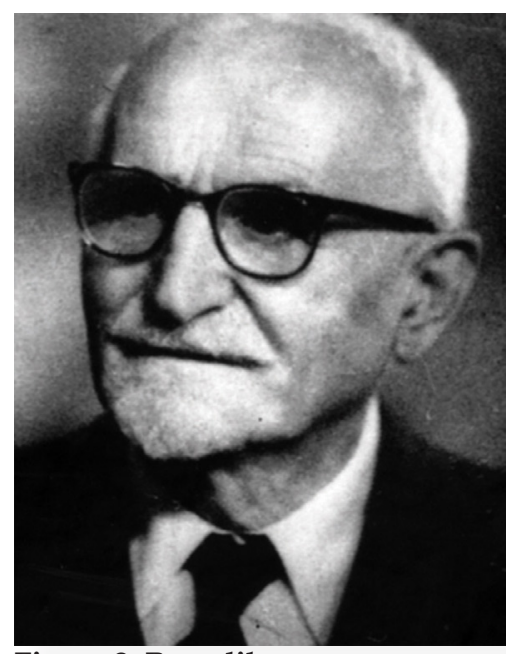

Figure 2. Benediktos Adamantiades (1875-1962)

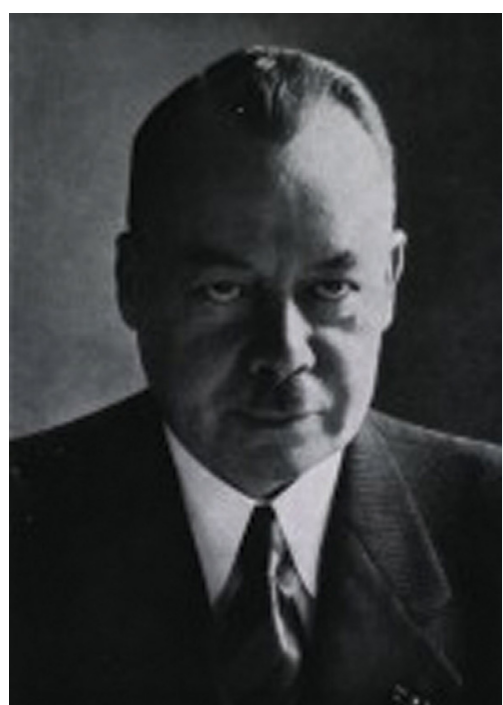

Figure 3. Hans Reiter (1881-1969). A courtesy of National library of Medicine 


\begin{tabular}{|c|c|}
\hline $\begin{array}{l}\text { Eponyms in dermatology } \\
\text { literature linked to the disorder } \\
\text { of genital area }\end{array}$ & Remarks \\
\hline Bartholin cyst [5] & $\begin{array}{l}\text { It occurs as a result of blockage to the Bartholin gland which was first described in } 1677 \\
\text { by Danish anatomist Caspar Secundus Bartholin (1655-1738). }\end{array}$ \\
\hline Buschke-Loewenstein Tumor [6] & $\begin{array}{l}\text { This is another name for giant condyloma accuminata of genital skin. It is named after } \\
\text { dermatologists from Germany, Abraham Buschke (1868-1943), (Fig. 4) and Ludwig } \\
\text { Loewenstein (1895-1959). }\end{array}$ \\
\hline Fournier's gangrene [7] & $\begin{array}{l}\text { Fulminating infection of the scrotum leading to gangrene and commonly associated } \\
\text { with diabetes. It is a type of necrotizing infection or gangrene usually affecting the } \\
\text { perineum. } \\
\text { It was first described by Baurienne in } 1764 \text { and is named after, Jean Alfred Fournier } \\
\text { (1832-1914), French dermatologist (Fig. 5). } \\
\text { Figure 5. Jean Alfred Fournier (1832-1914). A courtesy } \\
\text { of National library of Medicine. }\end{array}$ \\
\hline Klingsor Syndrome [8] & $\begin{array}{l}\text { This syndrome denotes to self-mutilation of the external genitals in psychiatric } \\
\text { patients. It was applied only to acts of genital self-mutation, involving religious delusions. } \\
\text { However, it was suggested that the syndromeshould also include cases which involve } \\
\text { genital self. Mutilation associated with all delusional syndromes. The name "Klingsor" } \\
\text { was based on a fictitious characterin Wagner's opera where Klingsor was a magician who } \\
\text { Castrated himself in an unsuccessful attempt to gain acceptance from the Knights of } \\
\text { the Grail. }\end{array}$ \\
\hline Lipschütz' ulcer $[9,10]$ & $\begin{array}{l}\text { Lipschütz acute genital ulcer is a rare distinctive cause of nonvenereal acute } \\
\text { genital ulcers that occurs particularly in adolescents described in 1913. The } \\
\text { etiology is unknown, although recent reports have associated it with the } \\
\text { Epstein-Barr virus. The diagnosis is made by exclusion after ruling out sexually } \\
\text { transmitted diseases, autoimmune causes, trauma, and other etiologies of genital } \\
\text { ulcerations. } \\
\text { It is named after Benjamin Lipschütz (1878-1931) Austrian dermatologist and } \\
\text { microbiologist. }\end{array}$ \\
\hline Mondor's disease $[11,12]$ & $\begin{array}{l}\text { Superficial thoracic wall and dorsal vein of the penis phlebitis are uncommon diseases. } \\
\text { Both are known as Mondor's disease. It is named after Henri Mondor (1885-1962), } \\
\text { (Fig. 6), a surgeon in Paris, France who first described the disease in 1939. }\end{array}$ \\
\hline
\end{tabular}




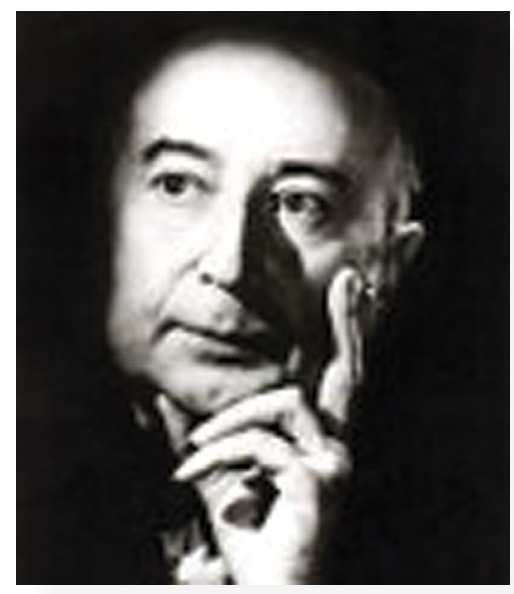

Figure 6. Henri Mondor (1885-1962).

\begin{tabular}{|c|c|}
\hline $\begin{array}{c}\text { Eponyms in dermatology } \\
\text { literature linked to the disorder } \\
\text { of genital area }\end{array}$ & Remarks \\
\hline $\begin{array}{c}\text { Paget disease } \\
\text { (extramammary) }[13,14]\end{array}$ & $\begin{array}{l}\text { Vulvar Paget, disease is the most common site of extramammary Paget's } \\
\text { disease (EMPD). The disease frequently associated with the underlying invasive skin } \\
\text { adnexal carcinoma or representing the migration of underlying internal malignancy, } \\
\text { especially anorectal and genitourinary cancer. It is named after an English surgeon and } \\
\text { pathologist, Sir James Paget, 1st Baronet (1814-1899), (Fig. 7). } \\
\text { Figure 7. Sir James Paget, 1st Baronet (1814 - 1899). } \\
\text { A courtesy of National library of Medicine. }\end{array}$ \\
\hline Priapism [15] & $\begin{array}{l}\text { It is a potentially painful medical condition, in which the erect penis or clitoris does } \\
\text { not return to its flaccid state, despite the absence of both physical and psychological } \\
\text { stimulation, within four hours. } \\
\text { The name comes from the Greek god Priapus, a fertility god often represented with a } \\
\text { disproportionately large and permanent erection. } \\
\text { The acronym, ASPEN syndrome, was proposed for the association of sickle cell } \\
\text { disease, priapism, exchange transfusion and neurological events. }\end{array}$ \\
\hline Prince Albert's piercing $[16,17]$ & $\begin{array}{l}\text { Prince Albert penile piercing is a metallic bead, which is anchored to the } \\
\text { urethral opening. Most of the body piercing is individually named, but the } \\
\text { renowned piercer Jim Ward, who developed the magazine Piercing Fans } \\
\text { International Quarterly in the late } 1970 \text { s, accepted that most of the names were } \\
\text { contrived. One of the most renowned piercings of the male genitals is the Prince Albert } \\
\text { (1819-1861), (Fig. 8). However, the idea that Prince Albert wore a penis ring to tie his } \\
\text { member down and prevent an offensive bulge in the breeches is a modern myth. } \\
\text { Concerns over the possibility of hepatitis B and C and human immunodeficiency virus } \\
\text { (HIV) transmission from body piercing are probably well founded. As with any surgical } \\
\text { procedure that involves piercing the skin, the possibility of bleeding and infection must } \\
\text { be considered. Other documented complications include urethral stricture, priapism, } \\
\text { paraphimosis, and recurrent condyloma acuminatum. Due consideration should also be } \\
\text { given to possible complications to the partner of the individual who has been genitally } \\
\text { pierced. A review of some of the piercing Web sites reveals anecdotal complications in } \\
\text { the form of trauma to the vagina or anus, teeth chipping, and choking. }\end{array}$ \\
\hline
\end{tabular}




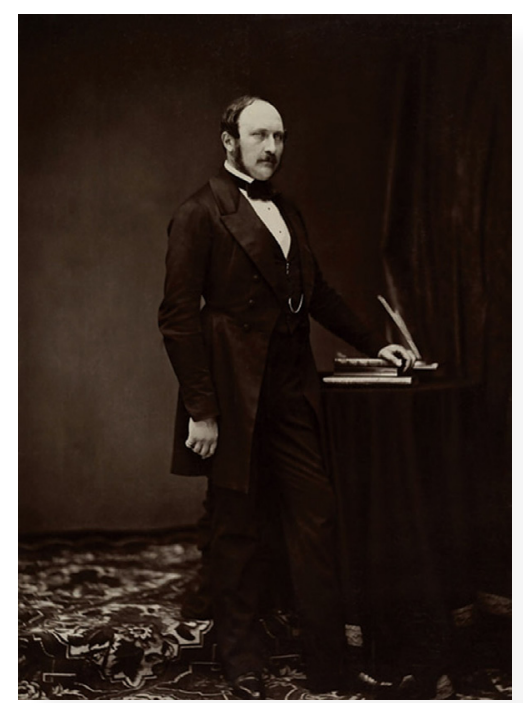

Figure 8. Prince Albert (1819-1861).

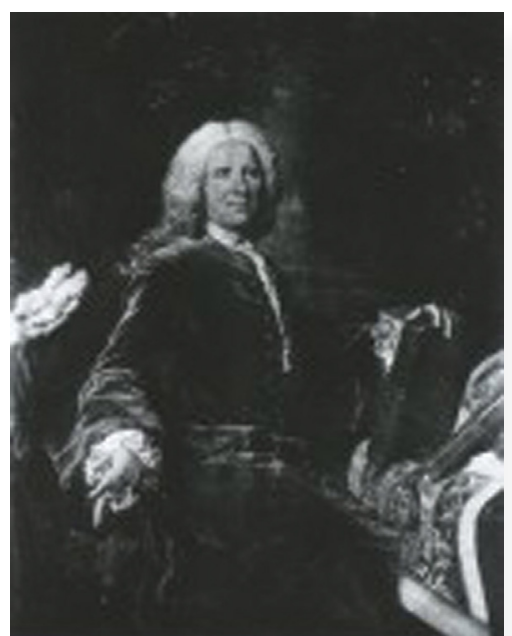

Figure 9. François Gigot de La Peyronie (1678-1747). A courtesy of National library of Medicine.

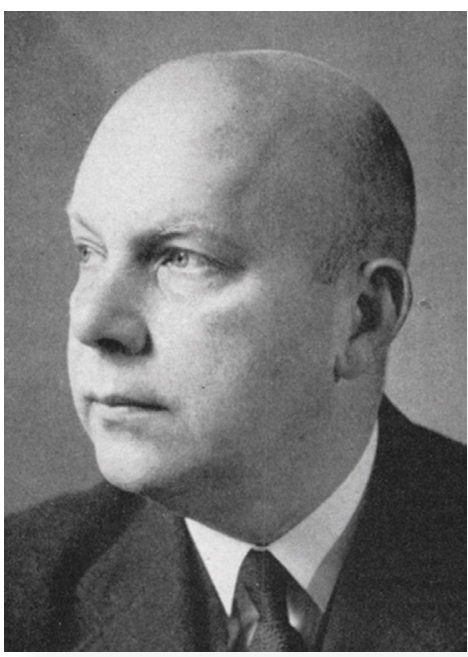

Figure 10. J.J.Zoon (1902-1952).

Reproduced from reference number 20.

\begin{tabular}{|c|l|}
\hline $\begin{array}{c}\text { Eponyms in dermatology } \\
\text { literature linked to the disorder } \\
\text { of genital area }\end{array}$ & \multicolumn{1}{c|}{ Remarks } \\
\hline Peyronie's disease [18] & $\begin{array}{l}\text { Also known as „Induratio penis plastica”, or more recently Chronic Inflammation of } \\
\text { the Tunica Albuginea (CITA), is a connective tissue disorder involving the growth of } \\
\text { fibrous plaques in the soft tissue of the penis. It causes erectile dysfunction. It is named } \\
\text { after François Gigot de La Peyronie (1678-1747), (Fig. 9) the first surgeon to Louis XV. }\end{array}$ \\
\hline Zoon balanitis [19,20] & $\begin{array}{l}\text { This is another name for Plasma cell balanitis, which is a benign asymptomatic } \\
\text { but chronic and erosive inflammatory condition of the glans penis and prepuce that } \\
\text { generally affects uncircumcised men in later years. Clinical presentation involves a } \\
\text { single, shiny, well defined reddish patch. It is named after J.J.Zoon (1902-1952), } \\
\text { (Fig. 10). }\end{array}$ \\
\hline
\end{tabular}

Table I. Selected Eponyms in dermatology literature linked to the disorder of genital area (continued)

\section{REFERENCES}

1. UStün C: A famous Turkish dermatologist, Dr. Hulusi Behçet. Eur J Dermatol 2002;12(:469-70.

2. Dimakakos PB, Tsiligiris B, Kotsis $\mathrm{T}$ : The physician B. Adamantiades and his contribution to the disease AdamantiadesBehçet. Int Angiol. 1999;18:176-81.

3. Lu DW, Katz KA: Declining use of the eponym „Reiter's syndrome" in the medical literature, 1998-2003. J Am Acad Dermatol. 2005;53:720-3.

4. Thyresson N: Girolamo Fracastoro and syphilis. Int J Dermatol. 1995;34:735-9.

5. Marzano DA, Haefner HK: The bartholin gland cyst: past, present, and future. J Low Genit Tract Dis. 2004;8:195-204.
6. Steffen C: The men behind the eponym--Abraham Buschke and Ludwig Lowenstein: giant condyloma (Buschke-Loewenstein). Am J Dermatopathol. 2006;28:526-36.

7. Haas LF: Jean Alfred Fournier (1832-1914). J Neurol Neurosurg Psychiatry. 1998;65:373.

8. Schweitzer I: Genital self-amputation and the Klingsor syndrome. Aust N Z J Psychiatry. 1990;24:566-9.

9. Kluger N, Garcia C, Guillot B: [Lipschütz acute genital ulcer]. J Gynecol Obstet Biol Reprod (Paris). 2009;38:528-30.

10. Holubar K: [Benjamin Lipschütz (1878-1931) and his significance in dermatology (dermatovirology)]. Hautarzt. 1986;37:266-9.

11. Ortega Calvo M, Villadiego Sánchez JM: [Mondor's disease: study of two topographic localizations]. An Med Interna. $2003 ; 20: 307-8$

\footnotetext{
Copyright by Khalid Al Aboud, et al. This is an open access article distributed under the terms of the Creative Commons Attribution License, which
} permits unrestricted use, distribution, and reproduction in any medium, provided the original author and source are credited. 